\title{
DISTRIBUSI DAN KOMPOSISI SAMPAH LAUT PESISIR DI KECAMATAN KUALA PESISIR KABUPATEN NAGAN RAYA
}

\section{DISTRIBUTION AND COMPOSITION COASTAL MARINE GARBAGE IN THE SUB-DISTRICT NAGAN RAYA DISTRICT}

\author{
${ }^{1}$ Ika Kusumawati, ${ }^{2}$ M. Arif Nasution, ${ }^{3}$ Alamsyah \\ ${ }^{1}$ Prodi Ilmu Kelautan, Fakultas Perikanan dan Ilmu Kelautan, Universitas Teuku Umar \\ Jalan Alue Peunyareng, Meulaboh, Aceh Barat 23615, Aceh ,Telepon (0655) 7003087 \\ ${ }^{1}$ Prodi Sumberdaya Akuatik, Fakultas Perikanan dan Ilmu Kelautan, Universitas Teuku Umar \\ Jalan Alue Peunyareng, Meulaboh, Aceh Barat 23615, Aceh ,Telepon (0655) 7003087 \\ ${ }^{1}$ Prodi Perikanan, Fakultas Perikanan dan Ilmu Kelautan, Universitas Teuku Umar \\ Jalan Alue Peunyareng, Meulaboh, Aceh Barat 23615, Aceh ,Telepon (0655) 7003087
}

Korespondensi : ikakusumawati@utu.ac.id

\begin{abstract}
ABSTRAK
Penelitian tentang distribusi dan komposisi sampah laut pesisir di Kecamatan Kuala Pesisir Kabupaten Nagan Raya yang di lakukan pada bulan Juli s/d Agustus tahun 2017 bertujuan untuk mengetahui distribusi dan komposisi sampah laut di pesisir yang terdapat di Kabupaten Nagan Raya. Penelitian ini menggunakan dua titik lokasi penelitian antara lain lokasi pertama pantai peunaga permai tempat wisata dan lokasi kedua pantai seunagan tempat pemancingan. Metode yang digunakan adalah deskriptif kuantitatif dan kualitatif yaitu metode pengamatan secara langsung untuk mengidentifikasi semua jenis sampah pesisir yang terdapat di ketiga stasiun pada dua titik lokasi penelitian. Hasil penelitian pada bulan Juli 2017 selama 28 hari jumlah sampah yang terdapat dipesisir laut pada dua lokasi penelitian sebanyak 6 jenis sampah antara lain sampah plastik, logam, kaca, karet, kayu olahan dan sampah kain-kain. Komposisi jenis sampah yang tertinggi terdapat pada lokasi pertama yaitu kawasan tempat wisata dengan jumlah total 15,931 dan jumlah persentase $(75 \%)$ sedangkan jumlah yang paling terkecil terdapat pada lokasi ke 2 yaitu pada kawasan pemancingan dengan jumlah total sampah 5.287 dan persentase (25\%). Jadi dampak pencemaran sampah tertinggi terdapat pada kawasan peunaga permai dengan jumlah rata-rata sampah 569 dan kawasan pemancingan dengan jumlah rata-rata sampah 192. Jenis sampah yang paling banyak pencemarannya pada dua lokasi penelitian yaitu jenis sampah plastik sedangkan sampah kaca paling sedikit pencemarannya.
\end{abstract}

Kata kunci : Komposisi, Sampah, Laut

\begin{abstract}
The research regarding distribution and sea waste composition in Kuala Pesisir District Nagan Raya Regency that conducted in July-August 2017. The aim of this research is to know distribution and sea waste composition in the coastal that overall Nagan Raya regency. This research used two point of research site are the first site (Peunaga Permai beach) and the $2^{\text {nd }}$ site Seunagan Beach. The research method used quantitative and qualitative descriptive namely direct observation for identifying all sea waste that obtained from three stations. The result showed in July 2017 for 28 days of amount of waste that gained from two sites as much as 6 type of sea waste incuding plastic waste, metal, mirror, rubber, wood and others. The highest composition of waste type that obtained from the tourism site with total number 15,931 and percentage $(75 \%)$ whereas the lowest of sea waste from fishing site (Seunagan Beach) with amount of waste 5.287 with percentage (25\%). Thus, the highest impact of pollution derived from Peunaga Permai Beach with amount average of waste 569 and fishing area with amount average 192. The type of waste the much more from two sites namely plastic waste whereas the waste from mirror were little.
\end{abstract}

Keywords : Composition, Waste, Sea 


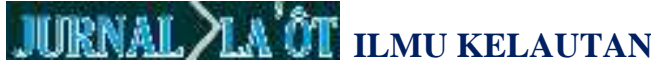

Volume I, Nomor 1, 2019

\section{PENDAHULUAN}

Wilayah pesisir merupakan daerah pertemuan antara darat dan laut. Kearah darat wilayah pesisir meliputi bagian daratan, baik kering maupun terendam air yang masih dipengaruhi oleh sifat-sifat laut seperti pasang surut, angin laut dan perembesan air asin, sedangkan kearah laut masih dipengaruhi oleh kegiatan manusia yang terjadi di darat seperti penggundulan hutan dan pencemaran serta proses alami yang terjadi seperti sedimentasi dan aliran air tawar (Slamet, 2007).

Sampah di daerah pesisir merupakan salah satu permasalahan kompleks yang dihadapi oleh suatu daerah yang berada dekat dengan pantai atau pesisir, Peunaga Permai merupakan sebuah kecamatan yang terletak di wilayah pesisir Kabupaten Nagan Raya. Kecamatan Kuala Pesisir merupakan salah satu pemukiman di sekitar pesisir yang menjadi aset wisata dan pemancingan bagi masyarakat di sekitar, pada umumnya masyarakat Nagan Raya. Dengan adanya sampah laut akan menimbulkan keresahan di masyarakat dengan keberadaan sampah yang telah mencemari wilayah pesisir dan laut.

Penelitian ini bertujuan untuk mengetahui distribusi dan komposisi sampah laut pesisir yang terdapat di Kabupaten Nagan Raya. Agar masyarakat dapat mengetahui bahayanya sampah yang terdapat di pesisir pantai terhadap kesehatan dan sumber ekonomi masyarakat berkelanjutan.

\section{METODE PENELITIAN Waktu dan Tempat Penelitian}

Available online at:

http://utu.ac.id/index.php/jurnal.html

Penelitian ini telah dilaksanakan pada bulan Juli s/d Agustus 2017 di Kecamatan Kuala Pesisir Kabupaten Nagan Raya dengan pantai - pantai wisata dan lokasi pemancingan yang menjadi titik pusat lokasi penelitian. Peneliti mengambil 2 titik pantai yang menjadi tujuan pengunjung pada tiap hari libur yaitu Pantai Peunaga Permai dan Pantai Seunagan.

\section{Desain Peneitian}

Peneliti menerapkan pendekatan deskriptif kuantitatif dan kualitatif dalam riset ini untuk menjelaskan masalah penelitian yang terfokus pada tujuan penelitian. Desain ini diharapkan mampu memberikan gambaran tentang distribusi dan komposisi sampah laut di Kabupaten Nagan Raya.

\section{Teknik Pengumpulan Data}

Berdasarkan lokasi terdapatnya sampah laut, maka untuk mengidentifikasi jenis sampah laut yang terdapat di pantai (Beached Marine Debris) lebih aplikatif dengan menggunakan metode stasiun. Data penelitian ini akan diambil pada saat setelah liburan akhir pekan, dikarenakan banyaknya sampah yang disebabkan oleh parawisata pantai dan pemancingan. Dalam penentuan stasiun dari 2 titik lokasi penelitian dapat dibagi menjadi 3 buah stasiun pada dua titik lokasi penelitian dengan jarak stasiun pengamatan sepajang pantai yang biasanya di jadikan lokasi tempat wisata dan tempat pemancingan antara lain : stasiun I dengan jarak panjang 100 meter dan lebar $\pm 20-50$ meter dari pesisir pantai, jarak antara stasiun I ke 


\section{LIDPN}

Volume I, Nomor 1, 2019

stasiun II yaitu dengan jarak \pm 500 meter, sedangkan jarak stasiun II ke stasiun III juga sama dengan jarak stasiun I ke stasiun II, dapat dilihat pada gambar di bawah ini:

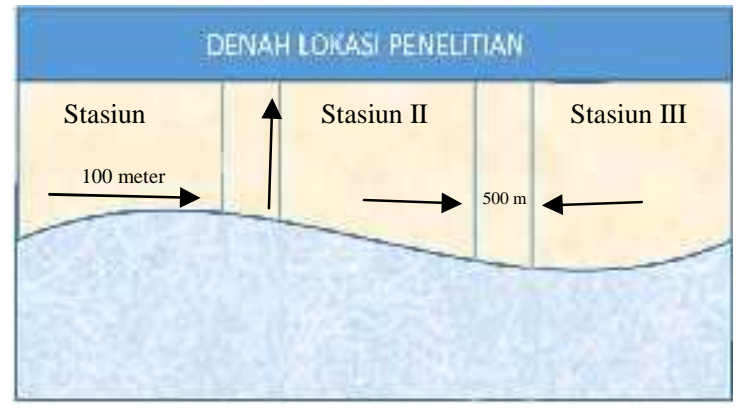

Gambar 1. Denah lokasi penelitia

\section{Teknik Analisis Data}

Untuk variabel sampah laut, ada beberapa langkah analisis yang akan dilakukan pada penelitian ini, yaitu:

1) Sampah laut yang tersebar di 2 titik lokasi penelitian akan dicatat berdasarkan jenis dan sumbernya;

2) Peneliti akan mendeskripsikan jumlah sampah berdasarkan jenis dan sumbernya dalam bentuk paparan statistik pada setiap titik lokasi penelitian;

3) Nilai rata - rata jumlah sampah berdasarkan jenis pada tiap lokasinya.

\section{Pengukuran Parameter Oseanografi Fisika}

(1)Pengukuran Arah dan Kecepatan Arus

Kecepatan arus diukur dengan menggunakan botol akua bekas sebanyak 2 kali. Botol akua bekas dibiarkan terbawa arus hingga tali lurus, setelah itu mencatat waktu tempuh sepanjang 7 meter dan di bidik dengan menggunakan kompas searah dengan tali untuk menentukan arah arus. Pengambilan kecepatan dan arah arus dilakukan di masing-masing stasiun.
Available online at:

http://utu.ac.id/index.php/jurnal.html

\section{(2)Gelombang}

Pengukuran gelombang dilakukan dengan mengukur puncak dan lembah sebanyak 5 kali pada tiang skala. Selama pengukuran dihitung waktunya dengan menggunakan stopwatch. Selain itu arah datang gelombang juga dilihat dengan menggunakan kompas.

\section{(3)Pasang Surut}

Pengukuran pasang surut dapat di tentukan dengan menentukan lokasi yang presentatif untuk pemasangan tiang pasut (tiang skala) dan mencatan posisinya dan memasang tiang pasut pada daerah yang diperkirakan tetap tergenang air apabila terjadi surut, sedangkan panjangnya tiang skala harus lebih besar dari tunggang pasut (tidal range). Misalnya, pada perairan dengan tunggang pasut sebesar $2 \mathrm{~m}$, maka ukuran papan skala ini harus lebih dari 2 m (Djaja, 1989).

(4)Pengamatan Visual Pantai dan Substrat Pengamatan visual dilakukan untuk memperhatikan vegetasi yang tumbuh di sekitar lokasi penelitian. Jenis substrat diketahui dengan menggunakan teknik meremas untuk membedakan jenis sedimen berpasir, pasir berlumpur dan lumpur.

\section{HASIL DAN PEMBAHASAN \\ Pengamatan Pertama pada Lokasi Tempat Wisata}

Hasil identifikasi jenis-jenis sampah di pesisir pantai yang terdapat ditempat wisata Desa Suak Puntong Kecamatan Kuala Pesisir Kabupaten Nagan Raya selama 28 hari sebanyak 6 jenis sampah dan 33 pecahan sampah antara lain 


\section{WIIRN}

Volume I, Nomor 1, 2019

sampah plastik memiliki nilai sampah yang terbanyak dengan pecahan sampah mencapai 11 jenis, sedangkan sampah kain-kain mencapai 6 jenis pecahan, juga di ikuti dengan sampah karet yang

Tabel 1. Jumlah sampah yang terdapat di masing-masing pada lokasi tempat wisata pantai peunaga permai Bulan Juli 2017

\begin{tabular}{clccccc}
\hline \multirow{2}{*}{ No } & \multirow{2}{*}{ Nama Sampah } & \multicolumn{3}{c}{ Lokasi Wisata } & Jumlah & $\begin{array}{c}\text { Rata- } \\
\text { Rata }\end{array}$ \\
\cline { 3 - 6 } & Stasiun I & $\begin{array}{c}\text { Stasiun } \\
\text { II }\end{array}$ & $\begin{array}{c}\text { Stasiun } \\
\text { III }\end{array}$ & & 382 \\
\hline 1 & Plastik & 3.249 & 3.660 & 3.783 & 10.692 & 382 \\
\hline 2 & Logam & 158 & 185 & 148 & 491 & 18 \\
\hline 3 & Kaca & 166 & 119 & 128 & 413 & 15 \\
\hline 4 & Karet & 453 & 409 & 337 & 1.199 & 43 \\
\hline 5 & Kayu Olahan & 889 & 847 & 712 & 2.448 & 87 \\
\hline 6 & Kain-Kain & 234 & 202 & 252 & 688 & 25 \\
\hline \multicolumn{2}{c}{ Total } & & & & $\mathbf{1 5 . 9 3 1}$ & $\mathbf{5 7 0}$ \\
\hline
\end{tabular}

Hal ini juga dapat dilihat pada gambar 2 grafik dibawah ini :

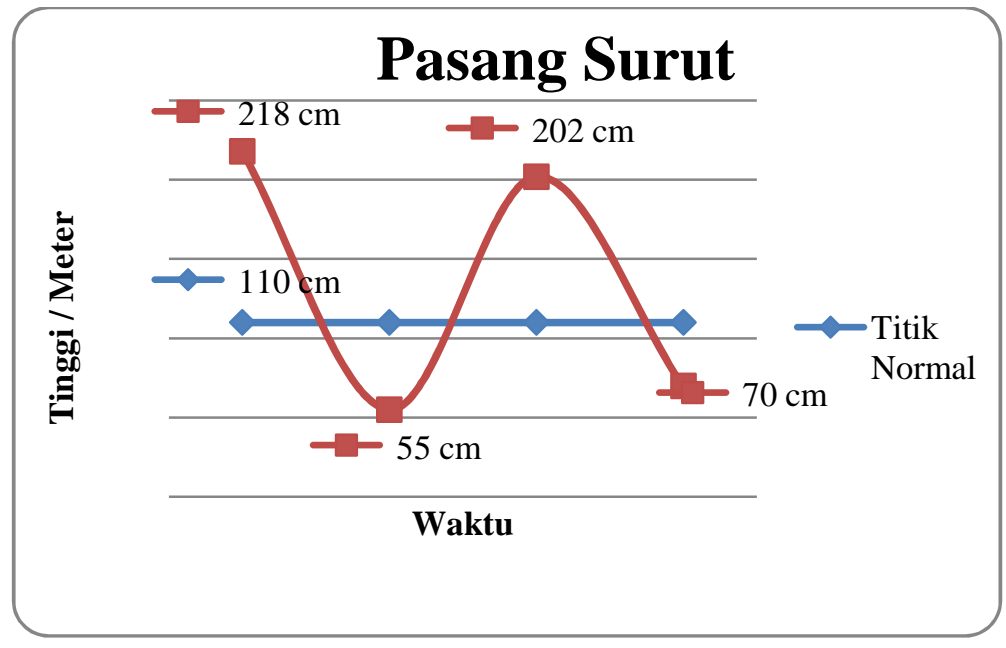

Gambar 2. Grafik jumlah total sampah pada ke tiga stasiun di lokasi tempat wisata pantai peunaga permai.

Dari hasil pengamatan di atas bahwa Lokasi Tempat Wisata Pantai Peunaga Permai Kecamatan Kuala Pesisir selama 28 hari pada ke tiga stasiun, yang posisi pertama sampah terbanyak terdapat pada sampah plastik mencapai nilai sebesar

Available online at:

http://utu.ac.id/index.php/jurnal.html

pecahannya mencapai 5 jenis, kayu olahan 5 jenis dan 3 jenis pecahan sampah lainnya yaitu jenis sampah logam dan kaca. Hal ini

dapat dilihat pada tabel di bawah ini : asi Wisata 


\section{LIIPR}

Volume I, Nomor 1, 2019

kaca dengan nilai rata-rata (15). Sampah plastik memiliki nilai tertinggi disebabkan karna di daerah tersebut banyak di kunjungi oleh parawisata baik lokal muapun luar daerah, dan juga di lokasi pantai peunaga permai banyak terdapat warung atau kafe untuk jajanan para wisata yang berkunjung ke pantai peunaga permai tersebut. Maka dari itu sampah plastik sangat banyak didapatkan di lokasi pantai disebabkan oleh para wisata dan para pedagang di lokasi pantai peunaga permai seperti bungkusan makanan, botol minuman, tutup botol, korek api dan lain lain. Sedangkan sampah kaca memiliki posisi terakir yang terdapat di pantai peunaga permai, sampah kaca banyak disebabkan oleh para pedangang seperti jenis sampah kaca botol minuman, toples kaca dan lain - lain. Sedangkan jumlah sampah berdasarkan stasiun yang diantaranya stasiun I, II dan III pada lokasi tempat wisata selama 28 hari dapat dilihat pada gambar di bawah ini:

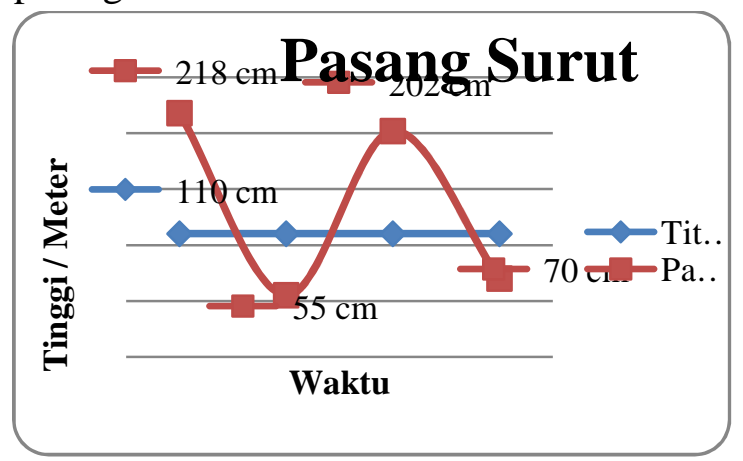

Gambar 3 : Grafik jumlah total sampah pada ke stasiun I di lokasi tempat wisata pantai peunaga permai.

Dari grafik di atas dapat diperjelaskan bahwa jumlah sampah terbanyak terdapat pada jenis sampah plastik yang berjumlah 3.249 buah sampah plastik dengan persentase (63\%), di ikuti
Available online at:

http://utu.ac.id/index.php/jurnal.html

dengan sampah kayu olahan 889 buah sampah kayu olahan dengan persentase (17\%), 453 buah sampah karet (9\%), 234 buah sampah kain-kain (5\%), dan yang posisi jumlah sampah terkecil terdapat pada sampah kaca 166 buah dan sampah logam 158 buah dengan persentase (3\%), dan juga pengamatan pada stasiun ke II dapat di lihat pada gambar di bawah ini :

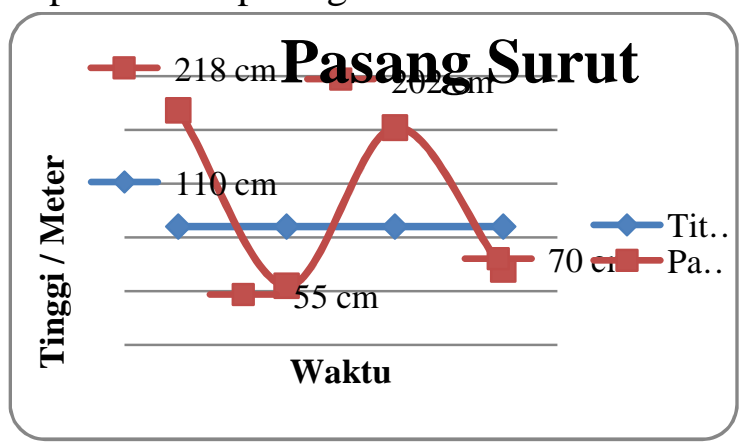

Gambar 4 : Grafik jumlah total sampah pada stasiun ke II di lokasi tempat wisata pantai peunaga permai.

Jumlah sampah terbanyak yang teridentifikasi pada stasiun II terdapat pada grafik di atas di pantai peunaga permai selama 28 hari yaitu terdapat pada sampah plastik dengan jumlah sampah 3.660 buah sampah plastik dengan persentase (67\%), diikuti dengan sampah kayu olahan 847 buah dengan persentase (16\%), 409 buah sampah karet (8\%), 202 buah sampah kain-kain (4\%), 185 buah sampah logam (3\%) dan yang memiliki posisi terakhir yaitu pada jenis sampah kaca 119 buah sampah kaca dengan persentase (2\%).

Indentifikasi identifikasi jumlah sampah pada stasiun ke III terbanyak terdapat pada jenis sampah plastik dengan jumblah 3.783 buah sampah plastik dengan persentase $(71 \%)$, dan diikuti oleh sampah kayu olahan 712 buah (13\%), 337 buah sampah karet (6\%), (5\%) sampah kainkain dengan jumlah sampah 252, sampah 


\section{WIIRN}

Volume I, Nomor 1, 2019

logam 148 buah (3\%) dan yang terakir terdapat pada sampah kaca yang jumlah sampah 128 buah dengan persentase (2\%), hal ini dapat dilihat pada gambar grafik dibawah ini:

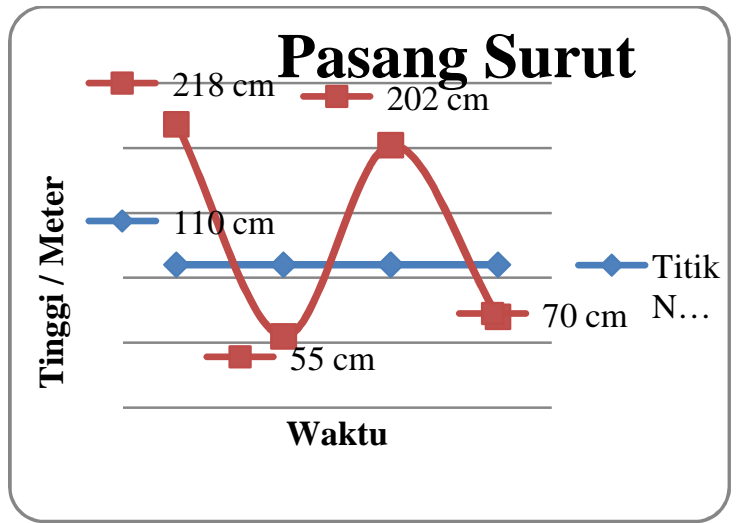

Gambar 5 : Grafik jumlah total sampah pada stasiun ke III di lokasi tempat wisata pantai peunaga permai
Available online at:

http://utu.ac.id/index.php/jurnal.html

Pengamatan Kedua pada Lokasi Tempat Pemancingan

Dari hasil pengamatan pada lokasi tempat pemancingan yang berlokasi di Desa Kuala Tuha Pantai Seunagan Kecamatan Kuala Pesisir Kabupaten Nagan Raya, jenis sampah yang teridentifikasi selama 28 hari sebanyak 6 jenis sampah dan 28 pecahan sampah antara lain sampah plastik memiliki 9 jenis pecahan, sampah kayu olahan memiliki 5 jenis, juga di ikuti dengan sampah kainkain yang pecahannya mencapai 4 jenis, karet juga 4 jenis dan 3 jenis pecahan sampah lainnya yaitu jenis sampah logam dan kaca. Hal ini dapat dilihat pada tabel 2 dibawah ini :

Tabel 2. Jumlah sampah yang terdapat di masing - masing stasiun pada Lokasi Tempat Pemancingan Pantai Seunagan Bulan Juli 2017

\begin{tabular}{clcccccc}
\hline \multirow{2}{*}{ No } & \multirow{2}{*}{ Nama Sampah } & \multicolumn{3}{c}{ Lokasi Pemancingan } & \multirow{2}{*}{ Jumlah } & \multirow{2}{*}{ Rata-Rata } \\
\cline { 3 - 6 } & & Stasiun I & Stasiun II & Stasiun III & & \\
\hline 1 & Plastik & 1.344 & 1.147 & 951 & 3.442 & 123 \\
\hline 2 & Logam & 73 & 91 & 72 & 236 & 8 \\
\hline 3 & Kaca & 61 & 16 & 27 & 104 & 4 \\
\hline 4 & Karet & 81 & 110 & 71 & 262 & 9 \\
\hline 5 & Kayu Olahan & 455 & 425 & 312 & 1.192 & 43 \\
\hline 6 & Kain-Kain & 54 & 44 & 53 & 151 & 5 \\
\hline \multicolumn{2}{r}{ Total } & & & & $\mathbf{5 . 3 8 7}$ & $\mathbf{1 9 2}$ \\
\hline
\end{tabular}

Hal ini juga dapat dilihat pada gambar 3 grafik di bawah ini : 


\section{LIIPI:}

Volume I, Nomor 1, 2019

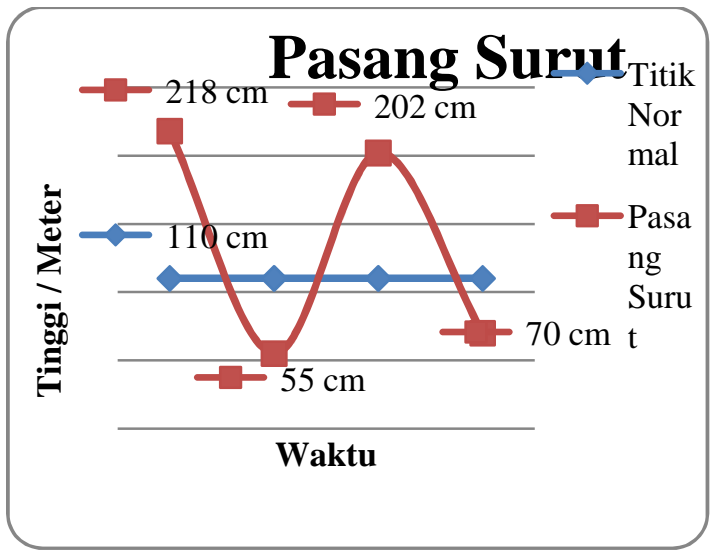

Gambar 6. Grafik jumlah totalsampah pada ke tiga stasiun di lokasi tempat pemancingan pantai seunagan

Dari hasil pengamatan di Lokasi Tempat Pemancingan Desa Kuala Tuha Kecamatan Kuala Pesisir Kabupaten Nagan Raya jumlah total sampah selama 28 hari pada ke tiga stasiun, yang posisi pertama sampah terbanyak terdapat pada sampah plastik yaitu dengan jumlah sampah 3.442 buah dan nilai rata-rata (123), 1.192 buah sampah kayu olahan dengan jumlah rata-rata (43), 262 buah sampah karet yang rata-rata (9), 236 buah sampah logam (8), 151 buah sampah kain - kain (5) dan yang terakir 104 buah sampah kaca dengan jumlah rata-rata (4). Sampah plastik juga memiliki nilai tertinggi yang terdapat di tempat pemancingan disebabkan karena di daerah pantai seunagan tersebut banyak di kunjungi oleh para pemancing baik masyarakat lokal muapun masyarakat luar daerah, dan juga di lokasi pantai seunagan banyak terdapat tempat pemancingan yang cocok untuk diaplikasikan alat penagkapan masyarakat seperti pancing dan lain-lain disebabkan daerah tersebut ombak air
Available online at:

http://utu.ac.id/index.php/jurnal.html

lautnya tidak terlalu tinggi dan lebih dekat dengan muara sungai, jadi para pemancing lebih suka memancing ikan di kawasan pantai seunagan. Maka dari itu sampah plastik sangat banyak didapatkan di lokasi pantai disebabkan para pemancing membawa bekal makanan dan sebagainya untuk keperluan para pemancing seperti bungkusan makanan, botol minuman, busa pelampung, korek api dan lain - lain. Sedangkan sampah kaca memiliki posisi terakir yang terdapat di pantai seunagan lokasi pemancingan, sampah kaca banyak disebabkan oleh masyarakat setempat maupun masyarakat luar yang biasa memancing di lokasi pantai seunagan tersebut seperti jenis sampah kaca botol minuman, pecahan kaca dan lain - lain. Sedangkan jumlah sampah berdasarkan stasiun yang diantaranya stasiun I, II dan III pada lokasi tempat pemancingan selama 28 hari dapat dilihat pada gambar di bawah ini:

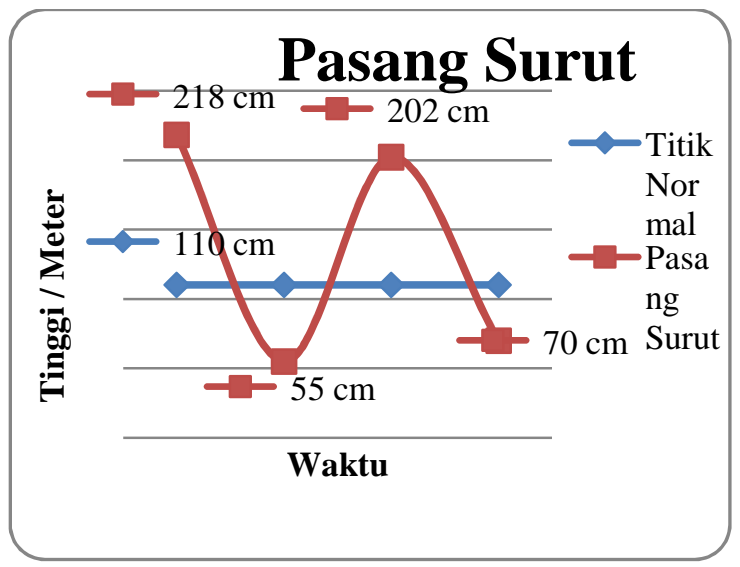

Gambar 7 : Grafik jumlah total sampah pada ke stasiun I di lokasi tempat pemancingan pantai seunagan.

Dari grafik di atas dapat diperjelaskan bahwa jumlah sampah terbanyak terdapat pada jenis sampah plastik yang berjumlah 


\section{LIIRAY}

Volume I, Nomor 1, 2019

1.344 buah sampah plastik dengan persentase (65\%), di ikuti dengan sampah kayu olahan 455 buah sampah kayu olahan dengan persentase (22\%), 81 buah sampah karet (4\%), 73 buah sampah logam (3\%), dan yang posisi jumlah sampah terkecil terdapat pada sampah kaca 61 buah dan sampah kain-kain 54 buah dengan persentase $(3 \%)$, dan juga pengamatan pada stasiun ke II tempat pemancingan dapat di lihat pada gambar di bawah ini :

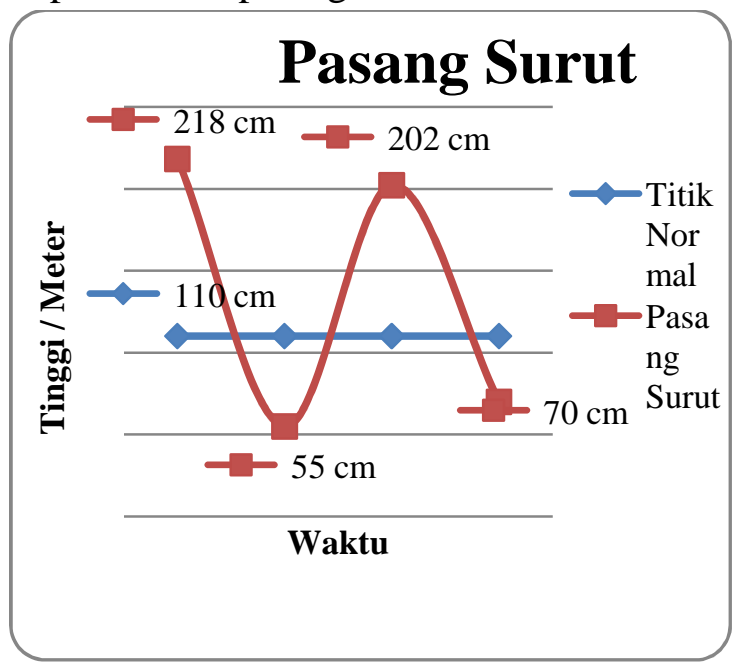

Gambar 8 : Grafik jumlah total sampah pada stasiun ke II di lokasi tempat pemancingan pantai seunagan

Jumlah sampah terbanyak yang teridentifikasi pada stasiun II terdapat pada grafik di atas di pantai seunagan lokasi pemancingan selama 28 hari yaitu terdapat pada sampah plastik dengan jumlah sampah 1.147 buah sampah plastik dengan persentase (63\%), diikuti dengan sampah kayu olahan 425 buah dengan persentase (23\%), 110 buah sampah karet (6\%), 91 buah sampah logam (5\%), 44 buah sampah kain-kain (2\%) dan yang memiliki posisi terakhir yaitu pada jenis sampah kaca 16 buah sampah kaca dengan persentase (1\%). Identifikasi jumlah sampah pada
Available online at:

http://utu.ac.id/index.php/jurnal.html

stasiun ke III yang terbanyak terdapat pada jenis sampah plastik dengan jumlah 951 buah sampah plastik dengan persentase (64\%), dan diikuti oleh sampah kayu olahan 312 buah (21\%), 72 buah sampah logam (5\%), (5\%) sampah karet dengan jumlah sampah karet 71 buah, sampah kain-kain 53 buah (3\%) dan yang terakir terdapat pada sampah kaca yang jumlah sampah 27 buah dengan persentase (2\%).

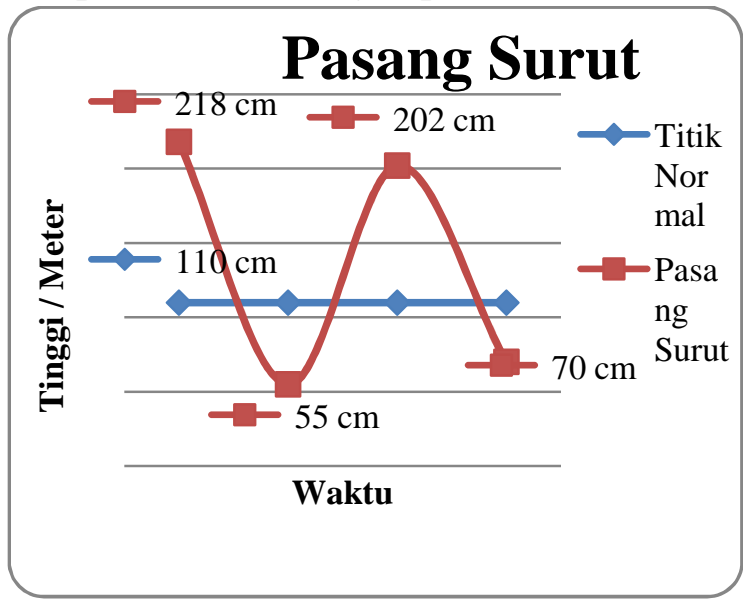

Gambar 9 : Grafik jumlah total sampah pada ke stasiun III di lokasi tempat pemancingan pantai seunagan

Dari hasil komposisi sampah laut pesisir di Kecamatan Kuala Pesisir Kabupaten Nagan Raya pada Bulan Juli 2017 yang berlokasi di Kawasan Tempat Wisata Desa Suak Puntong dan Desa Kuala Tuha Pantai Seunagan selama 28 hari yang teridentifikasi sebanyak 6 jenis sampah yaitu sampah plastik, logam, kaca, karet, kayu olahan dan jenis sampah kainkain, dapat dilihat dengan nilai persentase antara lain: 


\section{IIIDRN}

Volume I, Nomor 1, 2019
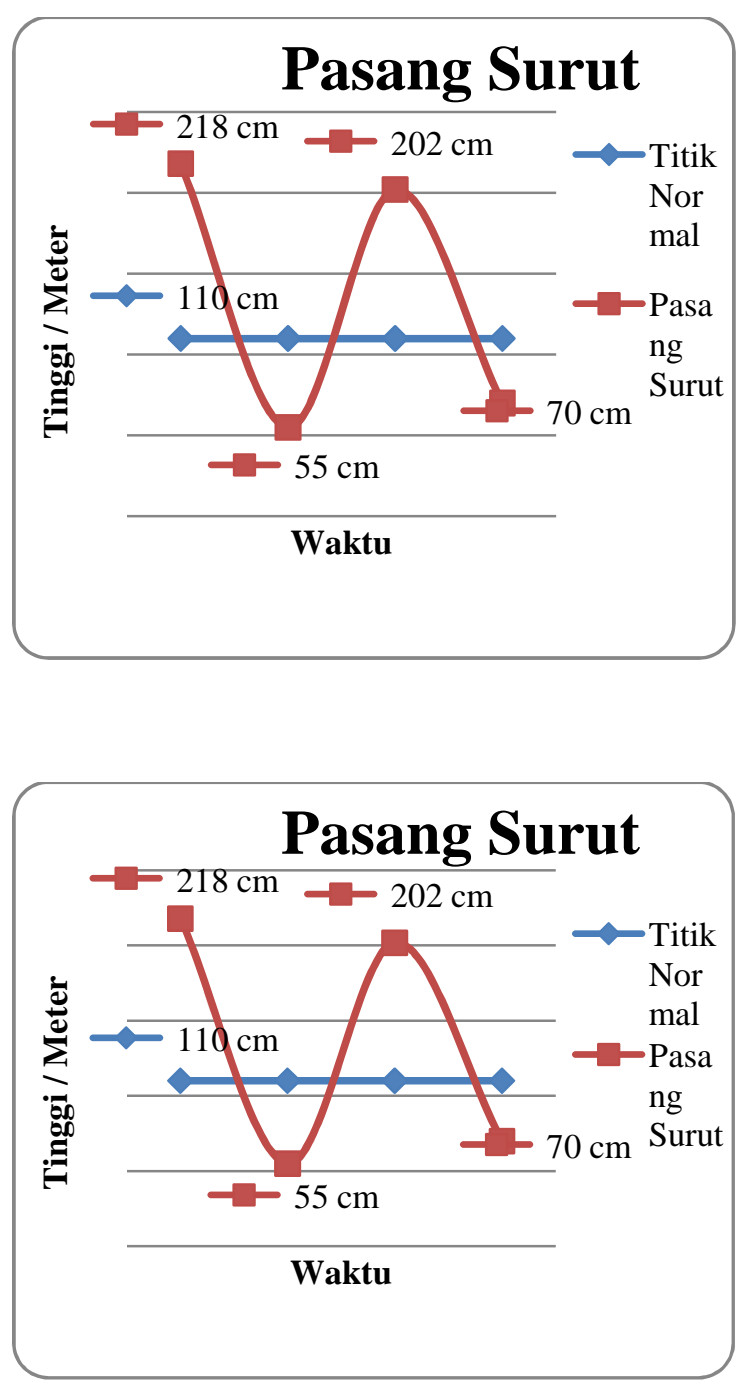

Gambar 10. Grafik persentase sampah pada dua lokasi penelitian di tempat wisata dan tempat pemancingan.

Dari hasil identifikasi sampah di dua lokasi penelitian yaitu kawasan tempat wisata dan kawasan peunaga permai selama 28 hari pada stasiun I, II dan III dapat disimpulkan bahwa nilai persentase sampah pada lokasi penelitian di tempat
Available online at:

http://utu.ac.id/index.php/jurnal.html

wisata yang terbanyak terdapat pada jenis sampah plastik dengan jumlah total sampah 10.692 buah sampah plastik dengan persentase $(67,1 \%)$, sampah kayu olahan dengan jumlah total sampah 2.448 persentase $(15,4 \%)$, sampah karet 1.199 buah persentase $(7,5 \%)$, kain-kain dengan jumlah total sampah 688 dan persentase (4,3 \%), Logam 491 (3,1 \%) dan yang posisi terakhir atau yang terkecil ialah jenis sampah kaca dengan jumlah 413 buah sampah kaca dengan persentase $(2,6$ $\%)$.

Pada lokasi penelitian ke dua yaitu di lokasi tempat pemancingan terdapat jumlah sampah terbanyak yaitu pada jenis sampah plastik dengan jumlah total 3.442 buah dan persentasenya (63,9 \%), sampah kayu olahan yang berjumlah $1.192(22,1$ $\%)$, sampah karet dengan jumlah total 262 (4,9\%), logam 236 (4,4\%), kain - kain $151(2,8 \%)$ dan jenis sampah yang paling sedikit atau terkecil yaitu terdapat pada jenis sampah kaca dengan jumlah total 104 dan persentaenya (1,9\%),

Dari hasil identifikasi selama 28 hari jumlah sampah yang terdapat di dua lokasi penelitian yaitu tempat wisata dan tempat pemancingan di kecamatan kuala pesisir kabupaten nagan raya, hal ini dapat dilihat pada gambar grafik 5 antara lain : 


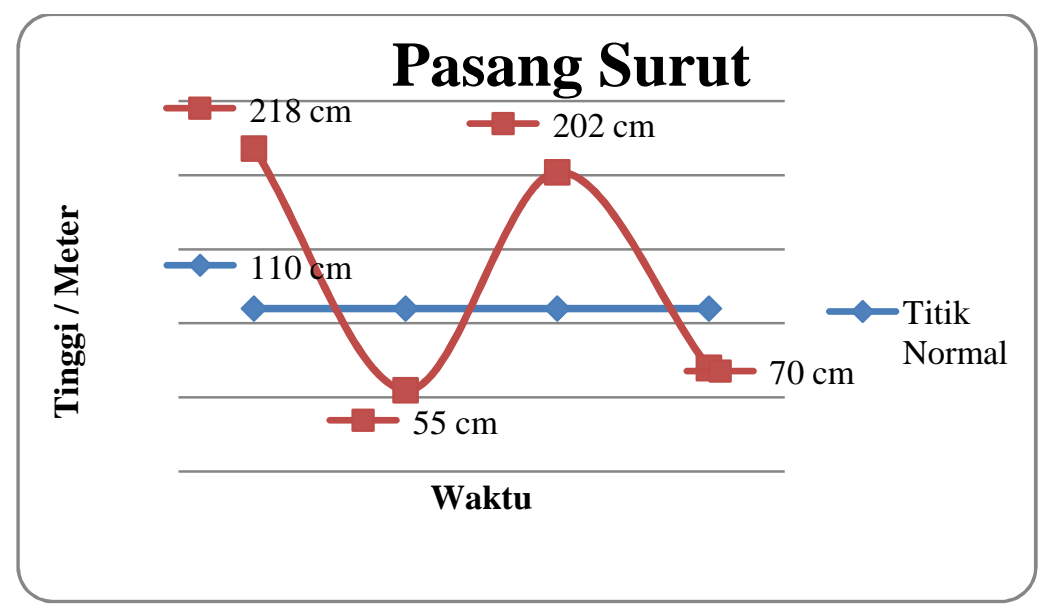

Gambar 11 : Grafik jumlah total sampah pada ke dua tempat lokasi penelitian, Tempat wisata dan tempat pemancingan

Dari hasil grafik diatas dapat dijelaskan bahwa sampah yang tertinggi terdapat pada dua lokasi penelitian yaitu pada lokasi pertama tempat wisata pantai peunaga permai dengan jumlah nilai total sampah sebanyak 15.931 sampah, sedangkan sampah yang paling terendah terdapat pada lokasi kedua yaitu lokasi pemancingan pantai seunagan dengan nilai total sampah 5.387 sampah.

Hal ini banyaknya pengunjung yang tidak bertanggung jawab yang membuang secara sembarangan sampah seperti makanan, botol, puntung rokok, dan lain sebagainya. Sampah yang dibuang nantinya terbawa arus laut dan selanjutnya meningkatkan jumlah dan volume sampah di perairan.

Tempat wisata di pantai peunaga permai, dampak sampah yang banyak di sebabkan oleh para wisata, penduduk dan pedagang di kawasan pesisir pantai peunga permai tersebut, seperti yang di kemukakan oleh Dainur (1995), yang bahwa tempat umum adalah tempat yang memungkinkan banyak orang berkumpul dan melakukan kegiatan termasuk juga tempat perdagangan. Jenis sampah yang dihasilkan dari tempat semacam itu dapat berupa sisa-sisa makanan (garbage), sampah kering, abu, sisa bangunan, sampah khusus, dan terkadang sampah berbahaya.

Jumlah sampah yang terbanyak terdapat dikedua lokasi penelitian dari hasil identifikasi sampah tersebut yaitu jenis sampah plastik yang berceceran di persisir pantai tempat lokasi penelitian dapat dilihat pada gambar grafik 2 dan 3, Plastik merupakan konsumsi umum pada masyarakat moderen, sebagian besar konsumsi plastik hanya digunakan sekali. Akibatnya tumpukan sampah plastik akan mencemari lingkungan dan menjadi sampah laut (Wang et al., 2016). Banyaknya sampah plastik yang ditemukan di pesisir pantai yang ditemukan juga sesuai dengan penelitian Hastuti pada tahun 2014 di wilayah pesisir Pantai Indah Kapuk Jakarta yang mencapai $77,7 \%$.

Pencemaran wilayah pesisir dapat didefinisikan sebagai masuknya atau dimasukannya makhluk hidup, zat, energi, 


\section{LIIRT:}

Volume I, Nomor 1, 2019

dan/atau komponen lain ke dalam lingkungan pesisir akibat adanya kegiatan setiap orang sehingga kualitas pesisir turun sampai ke tingkat tertentu yang menyebabkan lingkungan pesisir tidak dapat berfungsi sesuai dengan peruntukannya (UU Nomor 1 Tahun 2014). Secara lebih spesifik pencemaran wilayah pesisir didefinisikan sebagai masuknya zat atau energi, secara langsung maupun tidak langsung oleh kegiatan manusia ke dalam lingkungan laut termasuk daerah pesisir pantai, sehingga hayati, kesehatan manusia, gangguan terhadap kegiatan di laut, termasuk perikanan dan penggunaan lain-lain yang dapat menyebabkan penurunan tingkat kualitas air laut serta menurunkan kualitas tempat tinggal dan rekreasi (KLH, 1991 dikutip oleh Mukhtasor, 2006).

Menurut Mukhtasor (2006), tercemarnya wilayah pesisir tidak hanya merugikan secara ekonomi karena penggunaan kawasan pesisir dan laut sebagai area pariwisata dan rekreasi, namun kerugian juga menimpa nelayan yang hasil tangkapannya berkurang. Menurut Kusnandar (2008), masyarakat di sekitar kawasan pesisir merupakan komponen penderita utama akibat pencemaran lingkungan tersebut. Pencemaran lingkungan akan menimbulkan berbagai penyakit antara lain Infeksi Saluran Pernapasan Atas (ISPA), diare, penyakit kulit, dan lain-lain. Penderitaan tersebut secara otomatis akan meningkatkan biaya pengeluaran yang dialokasikan untuk pengobatan. Masyarakat yang menderita sakit juga akan mengalami kehilangan
Available online at:

http://utu.ac.id/index.php/jurnal.html

pendapatan. Selain itu, adanya pencemaran juga akan menyebabkan menurunnya kualitas dan kuantitas sumber pendapatan terutama bagi masyarakat yang tergantung pada sumberdaya alam pesisir.

Dampak pencemaran dikawasan pesisir terhadap aspek kehidupan masyarakat dapat dilihat dari aspek ekologi menurut para peneliti yaitu : Terjadinya abrasi dan sedimentasi pantai, berkurangnya produksi ikan akibat overfishing, kerusakan terumbu karang, serta kerusakan kualitas air laut akibat pencemaran pesisir laut (Dahuri, 2002).

\section{Parameter Oseanografi}

\section{Kecepatan Arus}

Kecepatan arus yang terdapat di lokasi pantai peunaga permai dan pantai seunagan pada bulan Juli - Agustus 2017 antara lain dapat di lihat pada tebel sebagai berikut ini: 
Tabel 3. Kecepatan arus pada dua lokasi penelitian bulan Juli - Agustus 2017.

\begin{tabular}{|c|c|c|c|c|c|c|c|c|}
\hline \multirow[b]{2}{*}{ Stasiun } & \multicolumn{4}{|c|}{ Tempat Wisata } & \multicolumn{4}{|c|}{ Tempat Pemancingan } \\
\hline & $\begin{array}{c}\text { Jarak } \\
(\mathrm{s})\end{array}$ & $\begin{array}{c}\text { Waktu } \\
\text { (detik) } \\
(\mathrm{t})\end{array}$ & $\begin{array}{c}\text { Kecepata } \\
\mathbf{n}(\mathbf{m} / \mathbf{s}) \\
\mathrm{V}=(\mathrm{s} / \mathrm{t})\end{array}$ & $\begin{array}{l}\text { Arah } \\
\text { Angin }\end{array}$ & $\begin{array}{c}\text { Jara } \\
\mathbf{k} \\
(\mathrm{s})\end{array}$ & $\begin{array}{c}\text { Waktu } \\
\text { (detik) } \\
(\mathrm{t})\end{array}$ & $\begin{array}{c}\text { Kecepata } \\
\mathbf{n}(\mathbf{m} / \mathbf{s}) \\
\mathrm{V}=(\mathrm{s} / \mathrm{t})\end{array}$ & $\begin{array}{l}\text { Arah } \\
\text { Angin }\end{array}$ \\
\hline $\begin{array}{l}\text { Stasiun } \\
\text { I }\end{array}$ & $7 \mathrm{~m}$ & 20,18 & 0,35 & $\begin{array}{c}48^{0} \text { Timur } \\
\text { Laut }\end{array}$ & $7 \mathrm{~m}$ & 23,20 & 0,30 & $\begin{array}{c}44^{0} \text { Timur } \\
\text { Laut }\end{array}$ \\
\hline $\begin{array}{l}\text { Stasiun } \\
\text { II }\end{array}$ & $7 \mathrm{~m}$ & 17,23 & 0,41 & $\begin{array}{c}56^{0} \text { Timur } \\
\text { Laut }\end{array}$ & $7 \mathrm{~m}$ & 19,12 & 0,37 & $\begin{array}{c}52^{0} \text { Timur } \\
\text { Laut }\end{array}$ \\
\hline $\begin{array}{l}\text { Stasiun } \\
\text { III }\end{array}$ & $7 \mathrm{~m}$ & 18,11 & 0,39 & $\begin{array}{c}51^{0} \text { Timur } \\
\text { Laut }\end{array}$ & $7 \mathrm{~m}$ & 21,19 & 0,33 & $\begin{array}{c}48^{0} \text { Timur } \\
\text { Laut }\end{array}$ \\
\hline \multicolumn{2}{|c|}{ Total } & 55,52 & 1,14 & & & 63,51 & 1,00 & \\
\hline \multicolumn{2}{|c|}{ Rata-rata } & 18,51 & 0,38 & $\begin{array}{c}52^{0} \text { Timur } \\
\text { Laut }\end{array}$ & & 21,17 & $\mathbf{0 , 3 3}$ & $\begin{array}{c}48^{0} \text { Timur } \\
\text { Laut }\end{array}$ \\
\hline
\end{tabular}

Dari hasil tabel diatas dapat disimpulkan bahwa kecepatan arus yang terjadi pada dua lokasi penelitia antara lain pantai peunaga permai yang paling tinggi yaitu terdapat pada stasiun 2 dengan kecepatan arus $0,41 \mathrm{~m} / \mathrm{s}$ dan kurun waktu 17,23 detik, sedangkan yang paling terendah terdapat pada stasiun 1 yaitu dengan kecepatan arus $0,35 \mathrm{~m} / \mathrm{s}$ dan kurun waktu 20,18 detik. Sedangkan kecepatan arus yang terjadi di lokasi penelitian ke dua yaitu pantai seunagan, yang tertinggi terdapat pada stasiun 2 dengan kecepatan arusnya $0,37 \mathrm{~m} / \mathrm{s}$ dan kurun waktu 19,12 detik, sedangkan yang paling terendah terdapat pada stasiun 1 dengan kecepatan arus $0,30 \mathrm{~m} / \mathrm{s}$ dan kurun waktu 23,20 detik. Rata-rata kecepatan arus yang tertinggi pada kedua lokasi penelitian tersebut yaitu pada pantai peunaga permai tempat wisata dengan kecepatan arus 0,38 $\mathrm{m} / \mathrm{s}$ dan yang paling terendah terdapat pada lokasi penelitian pantai seunagan tempat pemancingan dengan rata-rata kecepatan arus $0,33 \mathrm{~m} / \mathrm{s}$. Jadi kecepatan arus di pantai peunaga permai dan pantai seunagan di katagorikan sedang $0,33 \mathrm{~m} / \mathrm{s}-$ $0,38 \mathrm{~m} / \mathrm{s}$, hal ini sesuai pendapat Mason (1981), yang mengemukakan bahwa kecepatan arus yang dikatagorikan sedang antara lain $(0,25 \mathrm{~m} / \mathrm{s}-0,5 \mathrm{~m} / \mathrm{s})$. Tinggi suatu gelombang sangat berpengaruh terhadap kecepatan dan arah anggin, jadi menurut data BMKG Nagan Raya (2017) pada bulan Juli - Agustus di kedua lokasi penelitian tersebut yaitu kecepatan dan arah anggin dari NE (North East) dengan kecepatan rata-rata $22-27 \mathrm{KM} / \mathrm{Jam}$.

\section{Tinggi Gelombang}

Tinggi gelombang yang terdapat di lokasi pantai peunaga permai dan pantai seunagan pada bulan Juli - Agustus 2017 antara lain dapat di lihat pada gambar sebagai berikut: 


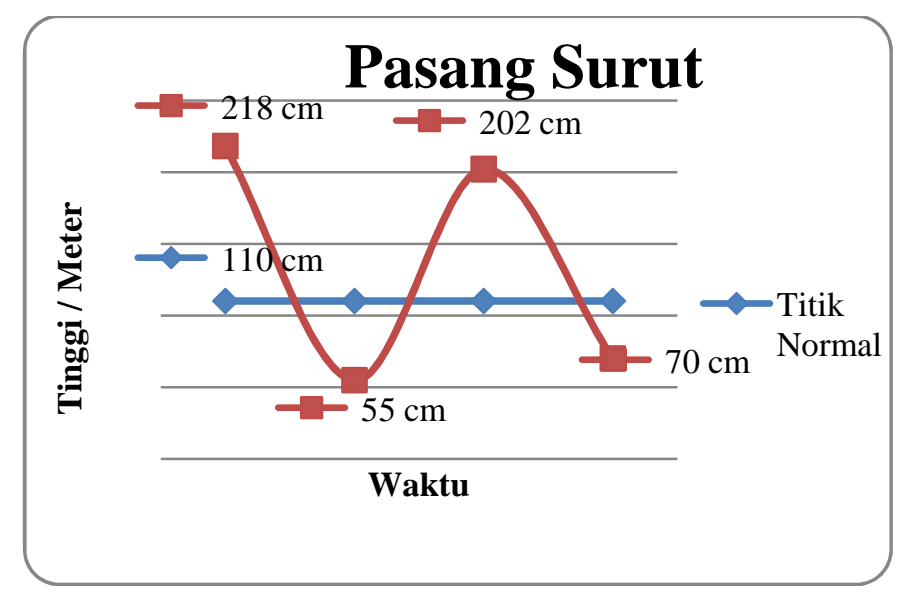

Gambar 12 : Grafik jumlah nilai rata - rata tinggi gelombang pada kedua lokasi penelitian tempat wisata dan pemancingan

Dari hasil grafik diatas dapat dijelaskan bahwa rata-rata tinggi gelombang yang tertinggi terdapat pada lokasi penelitian pertama yaitu tempat wisata dengan ratarata tinggi gelombang 3,45 meter, dan yang terendah terdapat pada lokasi penelitian kedua yaitu tempat pemancingan dengan jumlah rata-rata 3,38 meter. Hal ini hampir sama dengan data BMKG Nagan Raya (2017) pada bulan Juli - Agustus di kedua lokasi penelitian tersebut yaitu tinggi gelombang pada bulan Juli - Agustus 2017 dengan rata-rata 3,5 meter. Maka dapat membuktikan bahwa tinggi gelombang suatu daerah pesisir akan membuat terakumulasi sampah di suatu lokasi dengan adanya gelombang berpotensi mengaduk sampah dikolom perairan atau mengendap pada substrat naik ke permukaan, sehingga mudah terbawa oleh arus dan terakumulasi di suatu tempat. Kondisi tersebut sesuai pendapat Brunner (2014) yang bahwa tingginya gelombang terjadi di perairan dapat menimbulkan pengadukan, sehingga sampah yang terdapat didasar akan terangkat ke permukaan sehingga akan membentuk akumulasi sampah pada suatu daerah/kawasan.

\section{Pasang Surut}

Pasang surut yang terjadi di kedua lokasi penelitian yaitu pantai peunaga permai dan pantai seunagan pada bulan Juli - Agustus 2017 antara lain dapat di lihat pada gambar grafik di bawah ini: 


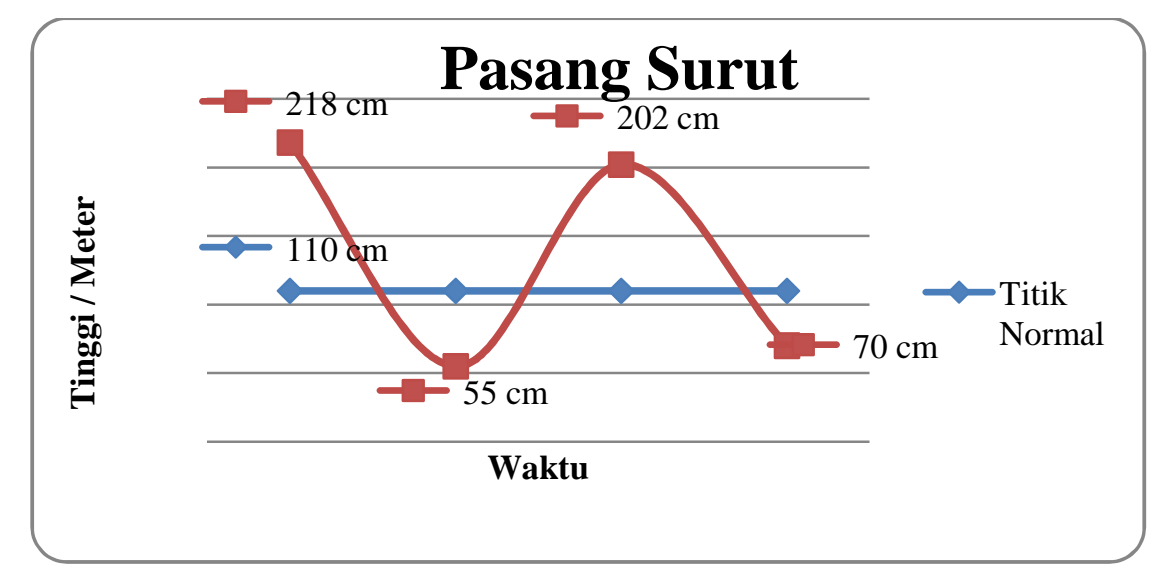

Gambar 13 : Grafik jumlah tinggi pasang surut yang terjadi pada dua lokasi penelitian tempat wisata dan pemancingan

Dari hasil grafik di atas dapat di perjelaskan bahwa, tinggi pasang surut air laut yang terjadi di dua lokasi penelitian antara lain pada jam 19.30 wib air laut mengalami pasang dengan ketinggian 218 $\mathrm{cm}$, setelah $\pm 1-2$ jam air laut pasang mengalami peneurunan atau surut pada jam 21.45 wib dengan ketinggian surut air laut $55 \mathrm{~cm}$ dan mengalami pasang kedua pada jam 01.25 wib dengan ketinggian pasang $202 \mathrm{~cm}$, pada jam 04.10 wib air laut mengalami penurunan lagi atau surut yaitu dengan ketinggian surut $70 \mathrm{~cm}$. Jadi ketinggian pasang dan surutnya air laut pada lokasi penelitian ini tidak jauh

\section{KESIMPULAN DAN SARAN \\ Kesimpulan}

Dari hasil kesimpulan di atas dapat disimpulkan bahwa jumlah total komposisi sampah pada dua lokasi penelitian dikawasan tempat wisata dan tempat pemancingan selama 28 hari di kecamatan kuala pesisir terdapat 6 jenis sampah, diantara lain, sampah plastik, logam, kaca, karet, kayu olahan dan sampah kain-kain. Jumlah total komposisi jenis sampah dari berbeda antara tinggi dan turunnya air laut dan kebiasaannya dilokasi ini terjadi dua kali pasang dan dua kali surut dalam satu hari, hal ini sama seperti yang di kemukakan oleh Romimohtarto dan Juwana (2007), yaitu jenis Pasang surut harian ganda (semi diurnal tide) dua kali pasang dan dua kali surut yang tingginya hampir sama dalam satu hari 24 jam, periode pasang surut rata-rata adalah 12 jam 24 menit. Dikuatkan oleh Priyana (1994), daerah-daerah pesisir mengalami dua kali pasang dan dua kali surut selama periode sedikit di atas 24 jam.

dua lokasi penelitian tersebut yang paling tertinggi terdapat pada lokasi pertama yaitu kawasan tempat wisata dengan jumlah total 15,931 buah sampah dengan jumlah persentase $(75 \%)$ dan yang pailing terkecil terdapat pada lokasi ke 2 yaitu pada kawasan pemancingan dengan jumlah total sampah 5.287 buah sampah dengan persentase $(25 \%)$. Jadi hal ini dapat disimpulkan bahwa dampak pencemaran sampah yang paling tertinggi yaitu pada kawasan peunaga permai 


\section{LIIIPN}

Volume I, Nomor 1, 2019

dengan jumlah rata-rata sampah 569, dan yang sedikit dampak pencemaran sampah terdapat pada kawasan pemancingan dengan jumlah rata-rata sampah 192 .

\section{Saran}

Berdasarkan paparan diatas, ada beberapa saran yang penulis berikan yaitu

(1) Bagi masyarakat, perlu membangun kepedulian masyarakat terhadap lingkungan pantai dan laut, agar bebas dari sampah, dengan demikian terbentuk hubungan timbal balik antara mahluk hidup dengan lingkungannya.

(2) Bagi pemerintah, pemerintah perlu membangun kawasan daerah percontohan yang bebas dari sampah, supaya masyarakat dapat meniru atau mengikuti contoh kawasan yang bebas sampah, baik bagi tempat wisata maupun tempat pemancingan dan lain-lain.

\section{DAFTAR PUSTAKA}

Badan Meteorologi Klimatologi dan Geofisika (BMKG). 2017. Stasiun Meteorologi Cut Nyak Dien Meulaboh. Nagan Raya.

Brunner, K. 2014. Effect of Wind and Wave-Driven Mixing on Subsurface Plastic Marine Debris Concentration. Thesis. University of Delaware.

Dahuri, R. 2002. Membangun Kembali Perekonomian Indonesia Melalui Sektor Perikanan dan Kelautan. LISPI: Jakarta.

Dainur. 1995. Kesehatan Lingkungan. EGC. Jakarta.

Djaja, R. 1989. Cara Perhitungan Pasut Laut dengan Menggunakan Metode
Available online at:

http://utu.ac.id/index.php/jurnal.html

Admiralty. Pusat Penelitian dan Pengembangan Oseanologi (P3O) LIPI, Jakarta.

Mason C. F. (1981). Biology of freshwater pollution. London : Longman Group Limited.

Mukhtasor. 2006. Pencemaran Pesisir dan Laut. Pradnya Paramita. Jakarta.

Priyana, Toto. 1994. Studi Pola Arus Pasang Surut di Teluk Labuhantereng Lombok - Lombok Nusa Tenggara Barat. Institut Pertanian Bogor: Bogor.

Romimohtarto, K. \& Juwana, S. 2007. Biologi Laut : Ilmu Pengetahuan tentang Biota Laut. Djambatan. Jakarta.

Slamet, B. 2007. Studi Kualitas Lingkungan Perairan di Daerah Budidaya Perikanan Laut di Teluk Kaping dan Pegametan Bali. Balai Besar Riset perikanan laut. Gondol. Bali.

Undang-Undang Republik Indonesia Nomor 1 Tahun. 2014. Tentang Perubahan Atas Undang-Undang Nomor 27 Tahun 2007 Tentang Pengelolaan Wilayah Pesisir Dan Pulau-Pulau Kecil. Jakarta.

Wang J., Tan Z., Qiu Q., Li M., 2016. The behaviors of microplastics in the marine environment. Faculty of Chemical Engineering and Light Industry, Guangdong University of Technology, China. Atlas of Science. 